\title{
Krajina vzpomínek. Kdo kreslí mapu „brněnského Bronxu"?
}

\author{
The Memories Landscape: Who Draws the Map \\ of the "Brno Bronx"? \\ Kateřina Sidiropulu Janků
}

\begin{abstract}
This article focuses on the process of urban place identity creation through culturally settled forms of remembering and the reproduction of social inequalities through the exclusion of memories of marginalized inhabitants. The theoretical base stands on the work of Pierre Nora, Jeffrey Alexander, Radim Marada, Csaba Szaló, Talja Blokland, David Sibley and Ryan Centner. Special attention is devoted to the perspective of neighborhood and neighbor relations, as well as the creation of relations to the city as a daily life place. The article empirically works with two sets of findings that are both bound to space in the so-called "Brno Bronx." One is the cultural milieu of remembering the inhabitance of this area by Germans who were expelled in 1945. The second set of knowledge comes from interviews with Slovak Roma who came to the area after 1945. The common topic of this part of the text is ethnicized remembering, which reproduces existing ethnic stereotypes but also enables the creation of ethnically defined categories for inhabitants within a given city quarter and the hierarchization of these categories.
\end{abstract}

KEY WORDS Brno, ethnic identification, memory, microcitizenship, neighborhood, Roma workmen, social marginalization

\section{Úvod}

Rozbité a opravené fasády, starostliví úředníci a rozverné děti, které jsou v detailním záběru identifikovatelné jako romské. ${ }^{1}$ To je tvář části Brna, které se lidově přezdívá „,brněnský Bronx“ a která byla na jaře 2013 prezentována v Urban centru Brno na výstavě „Integrovaný plán rozvoje města v problémové obytné zóně 2008-2015“ (Urban centrum 2013). Tento text je diskurzivní polemikou s viděním těch několika kilometrů čtverečních $\mathrm{v}$ liniích Francouzská/Bratislavská/Cejl jako problémové oblasti. Toto slovní spojení totiž z hlediska vývoje města po roce 1989 staví ,původní obyvatele“ (Brožovičová 2013) do pozice těch, kteří problémy způsobují. Oni sami však také mají mnoho problémů. Některé souvisí se samotnou architekturou a veřejnou správou místa, kde žijí, jiné jsou dílem ekonomické trans-

Sociální studia. Katedra sociologie FSS MU, 4/2013. S. 57-78. ISSN 1214-813X.

1 Text vznikl za finanční podpory Ministerstva kultury ČR v rámci projektu Pamét romských dělníků (DF12P01OVV029).

Děkuji frekventantům kurzu SOC 560/2 Sociologický výzkum z jara 2013 za podnětné pracovní prostředí a toleranci $\mathrm{k}$ mým učitelským vrtochům způsobeným hlubokým ponořením do výzkumného procesu. 
formace posledního čtvrtstoletí, jež výrazně postihla populaci dělnických a nízko kvalifikovaných profesí. Jak ukazují zkušenosti pamětníků/Romů bez ohledu na kvalifikaci, některé potíže způsobuje rozklížení rodinné a sousedské solidarity, které postupně přišlo s rozšířením dlouhodobé nezaměstnanosti a konzumních lákadel, měnících povahu všedního života $\mathrm{v}$ českých městech po roce 1989. Za fasádami, at' již zchátralými nebo opravenými za pomocí eurodotací či v rámci rezidentního podnikatelského záměru, se skrývají prríběhy rodin, které se v Brně ocitly v průběhu reindustrializace Československa po druhé světové válce. Dnes jsou příběhy těch, kteří přišli jako první, stejně jako príběhy mnohých dalších dnešních šedesátníků a sedmdesátníků, zapadané prachem nezájmu (o seniory obecně) a zamlžené rozpačitými pocity, které obklopují snahy o reinterpretaci socialistické minulosti České republiky. To, že zde prezentovaní pamětníci a tisíce dalších po celé České republice pochází ze slovenských romských osad, celou záležitost posouvá do deformní hysterické protorasistické optiky, se kterou se běžně můžeme setkat na diskusních fórech internetových novin, u nedělních obědů a ve školních třídách. Tento text přináší životní př́iběhy rodin, jejichž členové se v Brně ocitli coby pracovní migranti, ačkoli tak v době, kdy se jejich př́běh odehrál, nebyli označováni. Př́běhy ukotvené na Bratislavské ulici a v okolí konfrontuje s př́iběhem vzpomínání na vyhnání Němců z Brna v roce 1945, s putováním jedné pamětní desky z místa činu (shromaždiště moravských Romů za účelem transportu do pracovních táborů) do místa paměti (Muzea romské kultury) a etnografickým pozorováním oblasti v její všední dynamice.

\section{Identita městského prostoru - centrum, periferie, sousedství}

Moderní město je nejen správní jednotkou, ${ }^{2}$ je také platformou utváření sociální identity svých obyvatel. V sociologickém smyslu je moderní život bez kulis městského prostoru nepředstavitelný. Obyvatelé, návštěvníci a další uživatelé měst (např́iklad ti, kteří si o daných městech čtou, plánují je navštívit, sní, že v nich jednou budou žít, preferují filmy odehrávající se v oblíbených městech) skrze své jednání materializují v každodennosti institucionální řády (Berger a Luckmann 1999) opřené o městské prostory. Materializací zde myslím jednak hmotný projev daného institucionálního řádu (zanedbaný městský mobiliář mimo turistické centrum města dává tušit, jaké jsou investiční priority samosprávy související s budovaným obrazem města), jednak interpretaci sociálních skutečností skrze městský prostor (při vjezdu tramvaje do ulice Celj si někteří cestující instinktivně chytí tašku, aby zkontrolovali, jestli je někdo neokrádá).

Město také funguje jako značka (Bell a de-Shalit 2011), která administrativně a sociálně definuje své obyvatele a občany/měštany, odlišné od obyvatel ostatních měst; praktickou realizací tohoto rozměru městského prostoru je lokální patriotismus, ale také konkurence měst na postindustriálním trhu s urbánním bydlením, jak o něm hovoří současný diskurz kulturní politiky měst (Smolíková 2010). Zdá se, že ve vytváření městské značky má stále velké slovo takzvané městské centrum, kterému se věnuje řada sociálních vědců

2 Města a městské čtvrti, stejně jako národní státy, představují pro své správně-administrativní vymezení možnost vypovídat o vybraných sociálních jevech pomocí ucelených souborů demografických dat, která jsou k dispozici. 
(Brühl a kol. 2005; Haase a kol. 2011), včetně autorky tohoto textu (Sidiropulu Janků 2008, 2013a). Vedle významnosti centra pro upevňování vztahu obyvatel ke konkrétnímu městu se ale stále více prosazuje význam necentrálních městských čtvrtí. Jejich označení jako periferie již nepostačuje, nebot' městské čtvrti začínají zdůrazňovat svůj příběh vzniku a existence, který se definičně neodvíjí od městského centra. Německá socioložka Martina Löw, která se zabývá současnou sociální teorií prostoru a měst (Löw 2008, 2012), upozorňuje na mizení městského centra jako identitotvorného středobodu města (Löw 2013). Domnívám se, že jsme spíše svědky posilování necentrálních zdrojů identitotvorného vztahu občanů a dalších uživatelů se „svým“ městem, přičemž zároveň mocenská nadřazenost centra, stejně jako velké národní historie, neztrácí na relevanci, ale je doplňována ostatními identitotvornými matériemi městského života. Stále více lidí má také výlučný a patriotický vztah $\mathrm{k}$ více než jednomu městu, přičemž v tomto procesu rozdrobování prostorových sebe-identifikací není možné učinit jednoduchou dělicí linii mezi (bohatými) globály a (chudými) lokály (Bauman 2000). Těkavý pohyb těch nejchudších dnes díky poměrně levným možnostem přepravy na velké vzdálenosti narostl do globálních rozměrů a mezi nejchudšími a nejbohatšími existují mnohé variace prostorové rozložitosti všedního života. ${ }^{3}$

Při analýze pamět'ové stopy a sociálně-identitního rozměru života ve městě se nyní přesuňme k tématu sousedství. Právě prostorový rozměr sousedských vztahů významně určuje kvalitu života občanů měst, ale také jejich vztah k městu jako takovému. Architekti nového urbanismu definují sousedství jako prostor, který pěšky přejdeme za pět minut (Duany a Plater-Zyberk 1993). Dủležité je zde právě opření se o materiální esenci rezidenčního prostoru. V tomto smyslu sousedství patrně nikdy nenabyde oné virtuality obrazů měst z turistických pohlednic či televizního přenosu zahájení olympijských her. Ryan Centner (2011) se ve své studii městských čtvrtí Buenos Aires zaměřuje na nové formy přináležení $\mathrm{k}$ městu. Koncept sociálních práv (Marshall 1992) rozšiřuje dále k pojmu městského sociálního občanství (Walker 2006), které pojímá jako soubor aktivit vedoucích k nárokování na využití konkrétního městského prostoru. Jeho konceptuální východiska jsou založena na akcentování ekonomicko-politických rozdílů, kdy upozorňuje na to, že Argentina 21. století je chudší a levicověji orientovaná společnost, než byla realita západní Evropy 90. let 20. století, z níž Marshallův pojem sociálních práv vzešel. V kontextu jím zkoumaných čtvrtí pak samotnou možnost využívat městský prostor pro své potřeby vnímá jako jednu z kvalit městského

Uvedu zde dva krátké př́iklady z vlastní výzkumné praxe. Když jsem na jaře 2012 zamíŕila na první informační schůzku ohledně sběru pamětí romských dělníků do veřejné knihovny v Ostravě-Vítkovicích, bylo mi tehdejší vedoucí pobočky řečeno, že romské rodiny, které bych mohla oslovit, se často stěhují po Ostravě a okolí, a nemusí být tudíž snadné navázat s nimi kontakt a soustavnější spolupráci. Sama tuto těkavost hodnotila s lítostí nad tím, že se jim nedaří navázat soustavnější vztah s mladými romskými čtenáři, a že když už se to podaří, odstěhují se, nebo se naopak přistěhují noví, ale není jasné, na jak dlouho. Téhož roku na podzim jsme pořádali workshop pro zájemce o spolupráci v komunitním centru v Ostravě-Porubě. Požadavek, aby se někteří účastníci do diktafonu představili romsky, se setkal s pochichtáváním a rozpaky. Zato si jedna mladá dívka vybrala angličtinu a při představování uvedla, že žije v Torontu. Viditelně ovšem měla mezi místní mládeží kamarády, a dá se tak předpokládat, že k Ostravě-Porubě má, stejně jako k Torontu, osobní vztah, pocit přináležení. 
sociálního občanství. Centner na základě analýzy etnografických poznatků generuje pojem mikroobčanství, který pojímá jako:

kvazi-legální vztahy s místní samosprávou, které jsou specifické pro jednotlivé skupiny obyvatel a které obsahují jednak uznání a jednak poskytnutí služeb tak, aby garantovaly exkluzivní, i když dočasná, práva na specifikované legitimní použití městského prostoru. (Centner 2011: 4) ${ }^{4}$

V empirické části textu Centner představuje tři typy mikroobčanství, které však nepovažuje za vyčerpávající výčet. V prrípadě pojmu mikroobčanství se mu totiž (minimálně v této jeho studii) jedná spíše o představení analytického nástroje pro zachycení dynamiky nárokování veřejného prostoru $\mathrm{v}$ městských čtvrtích v podmínkách ekonomické nedostatečnosti a $\mathrm{s}$ přihlédnutím $\mathrm{k}$ politicko-správním specifikům daného městského (a státního) prostoru. Právě tím může být pojem mikroobčanství inspirativní pro sociologickou analýzu identity brněnské oblasti Bratislavská/Cejl. Jak a kým je tento prostor nárokován k užívání? Jak se $\mathrm{k}$ němu staví jeho obyvatelé a další uživatelé?

Německá socioložka Talja Blokland se dlouhodobě zabývá vztahem vzpomínání a vytváření sociálních skupin v prostorech městských sousedství (Blokland 2001, 2003, 2009). V deváté kapitole své monografie Městské svazky (2003) ukazuje, jak sdílená minulost a její performativní předávání společným vyprávěním historek z dob minulých ustanovuje legitimitu přináležení $\mathrm{k}$ sousedské komunitě v městském sousedství; a naopak, jak nemožnost účastnit se tohoto procesu může být účinným nástrojem ustanovování outsiderů. Ti, kteří nesdílejí minulost, se tak nemohou stát právoplatnými členy sousedské komunity. Perspektivou Centnerových mikroobčanství (2011) se však na sousedské vzpomínání můžeme dívat spíše jako na proces vyjednávání rozličných nároků na prostor městské čtvrti. Takto můžeme nejen rozumět tomu, jak mohou různé formy vzpomínání v prostoru městské čtvrti koexistovat. Centnerova perspektiva je také cenná svým konfliktním pojetím této koexistence. Nároky jedněch mohou přirozeně narážet na požadavky jiných, a městským sociálním občanem (Walker 2006) se tak stává každý, kdo nárok vznáší a v protitlaku nároků ostatních vyjednává.

Ve své americké studii Blokland (2009) ukazuje, jak s pamětovou stopou místa zacházejí tři skupiny obyvatel oblasti Little Italy v connecticutském New Havenu: gentrifikátoři (společensky lépe situovaní obyvatelé, kteří se ve čtvrti objevili po roce 1960 a neidentifikovali se ani s jednou z dvou následujících skupin) a (na základě sebeidentifikace) zástupci amerických Italů a chudí černošští obyvatelé (Blokland 2011: 1595-1596). Výsledky analýzy vyprávění, která Blokland zaznamenala ve svém etnografickém výzkumu, ukazují, že zástupci prvních dvou skupin dovedou interpretovat a politicky prosazovat svou verzi vyprávění o historii a vývoji městské čtvrti v souladu se svými rezidentními zájmy, zatímco chudí černošští obyvatelé v tomto směru selhávají. Jejich vyprávění nejsou ani explicitně identitotvorná ve smyslu posilování legitimity obývání čtvrti, ani se účinně nebrání nařčení z role narušitele v sousedství, kterou jim připisují reprezentanti prvních dvou skupin. Přitom jsou to podle Blokland právě chudí černošští obyvatelé, kteří jsou nejvíce prostorově závislí na sousedství, ve kterém

$4 \quad$ Všechny úryvky z anglických originálů přeložila autorka. 
žijí. Blokland tak dochází ke dvěma závěrům (2009: 1608): 1. Historická narativa o vytváření místa mají svůj každodenní politický rozměr. 2. Symbolické a fyzické užívání sousedského prostoru se nemusí překrývat. V následujícím textu přináším př́íklady každodenní politické práce s pamětí brněnské oblasti Bratislavská/Cejl, stejně jako kritický komentář k symbolickému a aktuálnímu užívání této čtvrti.

Z hlediska uvažování o identitotvorné dynamice městských sousedství je pozoruhodné, jak v České republice začaly v posledních letech žít svým životem mediální obrazy takzvaných romských ghett. Není totiž typické, že by sousedství přitahovalo masovou diváckou pozornost. To, že se tak děje v případě etnizovaných obrazů městských čtvrtí, svědčí o tom, že etnizace je všeobecně sdíleným kognitivním rámcem, který, slovy mediálních editorů, dobře prodává. Prodává těm, jejichž vidění světa je konformní se světonázorovou rovnicí Romové v ČR = ghetto = asociální a v ČR nežádoucí způsob života. Cílem tohoto textu je s pomocí analýzy pamět’ových stop brněnské oblasti Bratislavská/Cejl, která v obecném povědomí značku ghetta nese, tento obraz doplnit o další, a především v každodennosti žité obrazy opřené o vzpomínání. Než se ale vydám do ulic a ponořím se do vyprávění, zastavím se ještě u sociologie vzpomínání a otázek etnominoritních pamět'ových stop v moderní společnosti.

\section{Sociologie vzpomínání a etnizace vzpomínání}

Po sociologické reflexi prostoru přichází v posledních letech vlna zájmu sociologů o čas, především pak o minulost. Sociologické reflexe vzpomínání jsou značně inspirovány historickými pracemi, stejně jako sociologické reflexe prostoru pracemi geografickými a urbanistickými. Př́značným a logickým propojením obojího je poté zájem o vzpomínání etnických menšin a přistěhovalců (imigrací velká část etnizovaných a multietnických soužití začíná). V předmluvě ke knize Dějiny, pamět’ a migrace píše historik Jay Winter o existenci mlčících populací, že jsou z hlediska vzpomínání ,ztichlé, protože zde nemají být“ (Winter 2012: viii).

Winter zde má na mysli především nelegální přistěhovalce. Ticho, které obklopuje romské dějiny v České republice, je tichem populace ne svým občanským statusem nelegální, ale svým symbolickým společenským postavením nelegitimní, jak uvidíme v další části textu.

Pro současnou sociologii vzpomínání je zásadní dílo francouzského historika Pierra Nory, který upozorňuje na důležitost analytického rozlišení dějin a paměti (1998) a který také upřel ve svém díle pozornost na lokalizaci vzpomínání.

Brněnská oblast Bratislavská/Cejl je pro uvažování o lokalizaci paměti zajímavá tím, že vedle pouličního a mediálního obrazu romského ghetta je také sídlem Muzea romské kultury, jehož budova se nachází na malém náměstíčku lemovaném ulicemi Bratislavskou a Hvězdovou. Muzeum je jedno z mála institucionalizovaných míst, která v České republice lokalizují romskou pamět', je ale také místem, kde se uskutečňují aktivity podporující romskou etnokulturní identitu místních obyvatel. Přesto se nedá říct, že by to bylo místo čilého sousedského ruchu, byt’ je v přízemí veřejně přístupná kavárna. Osobně tomu spíše než jako selhávání snah Muzea o rozdmýchávání místního komunitního života rozumím tak, že právě ona absence ruchu v muzeu i kavárně dobře demonstruje nejen sekundární a stigmatizované 
postavení romské etnokultury v české společnosti, ale také její nesamozrrejmost. Podobně působí nevyslyšené nároky na odkoupení vepřína v Letech u Písku za účelem stavby památníku romského holocaustu. Romská pamět’ zkrátka dosud v české identitotvorné vzpomínkové mapě nenalézá své čitelné a nezpochybnitelné místo. Etnicky definované sociální nerovnosti mohou být totiž symbolicky konzervovány také skrze politiku paměti. Jak píší Irial Glynn a J. Olaf Kleist,

vzpomínky se ukazují jako velmi flexibilní nástroje, které mohou napomoci upravit kritéria př́slušnosti a začlenění do jakéhokoliv sociálního kontextu či politické preference. (2012: 241)

Moderní vzpomínání se stává nástrojem legitimizace stávajícího sociálního rádu a vnímání světa podél souřadnic národních států, jak o tom píše v kontextu migrace Rainer Bauböck (1998). K tomu patří také ustanovování etnické hierarchizace v paměti národních států, jak to v doslovu ke knize Aleny Wagnerové představující vzpomínky sudetských Čechů připomíná Miloš Havelka:

Dimenzi lidské paměti je třeba připomínat také s ohledem na její odlišnosti nebo i mezery u různých národů. Ty z nekonečného moře událostí ve své paměti nakonec uchovávají vždy jen některé, zejména události z časů krizí a zlomů, a především takové, jež se mohou stát manifestací národního sebevědomí, které přispívají k vytváření národní i skupinové soudržnosti a jejichž prostřednictvím se zpevňují tradice, tj. v zásadě významové sedimentace událostí a hodnot důležitých z určitého hlediska (národního, politického, církevního, regionálního atp.).

Nikoli tedy nezaujatý popis a objektivní výklad událostí, ale skutečnost, jak si lidé události pamatují a jak se mezi nimi tyto události tradují, má zásadní vliv na vznik kulturní a etnické rozdílnosti, kde se tvoří stereotypy ve vnímání vlastního národa i v hodnocení těch druhých, kde se udržují národní animozity a kde také přežívají etnická, sociální, politická i skupinová napětí. (Havelka 2000: 230-231)

Geograf David Sibley tuto dynamiku ve své stati na téma vztahu domova, lokality a národa popisuje ještě explicitněji. Domov je podle něj pro moderního člověka metaforou ráje, kde se chce cítit bezprostředně a neohrožován, a to legitimizuje diskreditaci všeho a všech, co by mohlo tyto pocity bezprostředního štěstí narušovat; na prvním místě etnicky definovaných menšin, jakými jsou v britském kontextu naprŕiklad Cikáni (Sibley 1995). Národní stát tak v moderní Evropě prostorově symbolizuje etnický domov reprezentantů dominantní etnokultury. Jak však upozorňuje Radim Marada, nemáme zde co do činění s jakousi společenskou patologií, spíše s průvodním jevem moderny:

Etnicky definované kolektivity jsou produktem i účastníkem politické hry v liberálních demokraciích. [...] V tomto pohledu liberální demokracie plodí problém inkluze v takové podobě, $\mathrm{v}$ jaké může být řešen právě jen v jejím rámci. (Marada 2006: 78)

Přes všechnu citlivost k rozmanitosti dějinných událostí a konstrukční povaze vzpomínání zůstávají současná kulturní studia paměti vesměs ukotvena v západní tradici rozumění času (Bird-David 2004) jako lineární veličině, kdy žijeme v přítomnosti obráceni k budoucnosti, přičemž minulost je oblast, do níž nelze vstoupit, nebot' je uzavřena dopředu ubíhajícím proudem času. To je důležité proto, že právě při takovém pojímání minulosti je možné 
uvažovat o existenci dějin jako legitimizačního rámce kultur a společností. Csaba Szaló s odkazem na Johannese Fabiana (1983) upozorn̆uje na to, že

[d]ruzí jsou v etnografických textech (v důsledku schizogenického používání času) zobrazovaní jako nám vzdálené bytosti - nejenom prostorově, ale i časově. (Szaló 2007: 92)

Tento text se pokouší o překonání této diskurzivní ruptury, a to přivedením reprezentantů různých sociálních skupin obyvatel a uživatelů čtvrti Bratislavská/Cejl na jednu stránku a do jednoho času, ve kterém se odehrává nárokování identitotvorné funkce tohoto městského prostoru. Zároveň ukazuje, jak je etnomajoritní diskurz implicitně rámován jako občanský a ve veřejném prostoru legitimní, zatímco etnominoritní je etnizován a představován jako neobčanský a ve veřejném prostoru nelegitimní.

\section{„Brněnský Bronx“ - utváření místa a metoda práce s pamětí}

Nevím, kdy a v jakém kontextu se pojem „brněnský Bronx“ začal objevovat a následně šiřit. Dnes se však již jedná o poměrně zažitý termín označující oblast kolem ulice Bratislavská. Já tuto lokalitu prostorově pojímám v souladu s vymezením v pilotní studii, kterou v roce 2007 zadal Úřad vlády ČR a v roce 2008 provedla Katedra sociologie FSS MU (Kašparová a kol. 2008). Úřad vlády našemu týmu tehdy dodal poměrně přesné vymezení na základě názvů ulic, případně dalších orientačních bodů, a mělo se jednat o sociálně vyloučenou lokalitu. ${ }^{5}$ Přehledová mapa oblasti je převzata ze závěrečné zprávy tohoto výzkumu (Kašparová a kol. 2008: 26) a ukazuje, že oblast obsahuje tři rovnoběžné ulice (od severu) Francouzskou, Bratislavskou a Cejl - tato ulice se na východní straně stáčí a oblast pomyslně uzavírá -, a dále príičně vedoucí ulice (od západu) Příční, Starou a Körnerovu, Soudní, Hvězdovou a Přadláckou.

Toto vymezení „brněnského Bronxu“ odpovídá veřejnoprávní představě o sociálně vyloučené lokalitě a také se kryje s historickou částí, kde žili němečtí a židovští Brňané, než v průběhu událostí druhé světové války Brno vesměs nedobrovolně opustili. Zároveň je potřeba zdůraznit, že se samosprávně nejedná o konzistentní městskou čtvrt', oblast je v jurisdikci dvou městských obvodů, a ani samotní obyvatelé nevnímají sousedskou solidaritu takto ohraničenu. ${ }^{6} \mathrm{~V}$ oblasti probíhají četné rekonstrukce, sídlí zde firmy; vedle toho starousedlíky, at již romské nebo etnicky české, stále více doplňují studenti a jiní gentrifikátoři (Brožovičová 2013).

Z hlediska obytného pohodlí se jedná o oblast značně nervózní a nepřátelskou. Městskou zeleň představují pouze betonem obklopené vzrostlé platany na plácku na rohu Hvězdové a Bratislavské, na Hvězdové je jedno neudržované dětské hřiště. Odpadkové koše zde téměř nejsou k vidění, na Cejlu je celý den hustý silniční provoz, Bratislavská i Francouzská jsou jednosměrné ulice, kterými neustále proudí auta, chodníky jsou úzké, a pokud se na nich

$5 \quad$ K diskusi nad etnickým vymezováním sociálně vyloučených lokalit viz Jakoubek (2006).

6 Např́ílad když jsme se za účelem sbírání pamětí romských poválečných přistěhovalců na Bratislavskou/Cejl procházeli v březnu 2012 oblastí s naší spolupracovnicí působící v komunitním centru na Bratislavské a pokoušeli se prostorově vymezit sousedství, v němž budeme paměti sbírat, odvětila, že „Cejl už je jinde“. 
člověk zastaví, okamžitě zatarasí proud kolemjdoucích, což vyvolává nervozitu. Vše doplňují všudypř́itomné psí výkaly a v poslední době stavební kontejnery doprovázející četné rekonstrukce.

Mapa 1: Oblast nazývaná brněnský Bronx

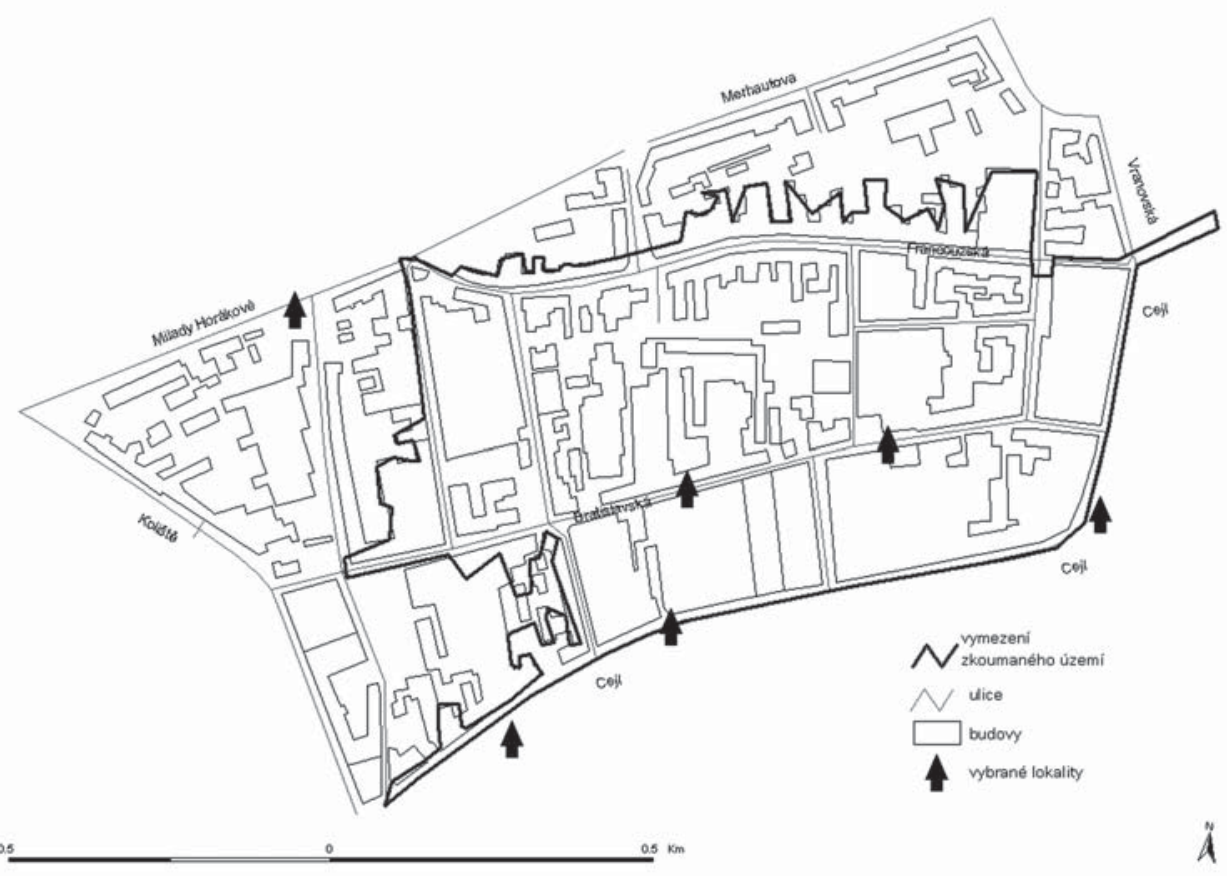

Zdroj: Kašparová a kol. (2008: 26)

Pojem „Bronx“ v sobě obsahuje asociace nebezpečí a cizosti nahlížené očima etnomajoritních ${ }^{7}$ obyvatel Brna, jak v rozhovoru o bydlení v oblasti a reakcích jejího okolí vyjadr̆uje nová obyvatelka, která si zde byt $\mathrm{v}$ roce 2003 koupila v průběhu svých vysokoškolských studií:

Tazatelka: Vy jste zmínila, že když k vám někdo jde na návštěvu, tak ani nechce nechat auto před domem. Vyslechnete si od svého okolí poznámky na téma toho, kde jste si vybrala, že budete bydlet?

$7 \quad$ Afiliace $\mathrm{k}$ české majoritní či české romské etno-kulturní identitě je ve vyprávěních označována pouze $\mathrm{v}$ př́ípadě, že má relevanci vzhledem $\mathrm{k}$ výkladu, což platí zvláště tam, kde pomáhá vysvětlit specifický vztah k „těm druhým“. Problematikou způsobů etno-kulturní identifikace a jejími epistemologickými a hodnotovými dimenzemi v projektu O leperiben / Pamět’ romských dělníků se zabývá rukopis autorky, který byl nabídnut k publikaci v časopise Biograf (Sidiropulu Janků 2013b). 
Vypravěčka: Ano, všichni jsou udiveni, že jsem si po přistěhování do Brna k bydlení vybrala právě tuhle čtvrt', protože má strašnou pověst. Všichni moji brněnští spolužáci to pokládají za cigánov, ghetto, Bronx - takové názvy té čtvrti mezi Brňáky běžně padají. Nebo tramvaji, která touto čtvrtí projíždí, se říká „CigánExpres“. Nikdo „slušný“ tu nechce bydlet, v Brně se to místo považuje za skutečně nebydlitelnou část. (etnomajoritní obyvatelka Hvězdové, duben 2013)

To, že vrstevníci nové obyvatelky Hvězdové neoceňovali její volbu, není v kontextu brněnské mentální mapy překvapivé. Toto vyjádření je však především důkazem o žitém užívání pojmu „Bronx“, v tomto kontextu poukazuje na symbolickou ostrakizaci z mapy bydlení. „Nebydlitelnost“ části kontrastuje s faktem, že oblast je poměrně hustě zabydlena, a symbolicky může asociovat nelegitimitu existence jejích obyvatel. Etnomajoritní obyvatelé, kteří se do čtvrti přistěhují, zdá se status čtvrti nepřeznačkovávají, podílejí se však na vyjednávání legitimity existence jejích obyvatel a „bydlitelnosti“ tohoto prostoru.

Podobně, jako neutěšený a zanedbaný, hodnotí stav oblasti romská návštěvnice Bratislavské; vidíme tedy, že čtvrt' je negativně hodnocena nejen z důvodu neatraktivního nebo problematického soužití s romskými obyvateli:

Tazatelka: Ale vy jste ř́kala, že byste nešla bydlet do centra, protože tam je ruch. Vy byste nechtěla bydlet $\mathrm{v}$ centru města, ani kdyby byly ty baráky opravené, hezké?

Žena: Tam ne, v té lokalitě. Protože tam se o to ta městská část nestará dobře. Tam je to všecko zanedbané. Tam to působí na člověka špatně. Takové bydlení. Tam vidíte jenom staré baráky, omítky oprýskané všecko, okna zničené, dveře. (občasná návštěvnice Bratislavské, moravská Romka, červen 2012)

Kromě napjatých sousedských vztahů, fyzické zchátralosti a deficitu veřejnoprávního okrašlovacího působení na místní veřejný prostor nelze opomenout viditelné kulturní ruptury prostoru, které jsou také v posledních letech inspirativním impulsem pro kulturní dění v oblasti. Opakovaně se na rohu Hvězdové a Bratislavské koná hudební festival s komunitním rozměrem Ghettofest, v komplexu budov bývalých kasáren na křižovatce Bratislavské a Soudní vzniká kreativní centrum, jehož reprezentanti hledají partnery ke spolupráci také mezi místními neziskovými organizacemi. Přes všechno dynamické dění v oblasti se však spíše jedná o prostor občansky utlumený až pasivní a z hlediska sousedského dění ne prŕliš aktivní. K takovému úsudku mne alespoň vedou první výzkumná zjištění projektu O leperiben / Pamět’ romských dělníků, která jsou podkladem pro tento text.

Projekt od března 2012 na katedře sociologie FSS MU tematizuje pamětovou identitotvornou stopu českých postindustriálních městských čtvrtí, z nichž se v posledních letech stala místa s nálepkou „sociálně vyloučené lokality“, a to na prŕikladu Brna - Bratislavské/ Cejlu - a Ostravy - Vítkovic ${ }^{8}$. Zatímco etnografická pozorování provádím především já coby socioložka, rozhovory s pamětníky záměrně vznikají jako kolektivní dílo např́č generacemi a profesním zázemím členů týmu, včetně sousedů a př́buzných pamětníků v roli tazatelů.

8 Vzhledem k povaze industriální minulosti Ostravska a aktuálnímu urbánnímu dění ve Vítkovicích, z nichž se pomalu stává „cigánov bez cigánư“, se zde projekt přirozeně rozšířil na celou ostravskou průmyslovou aglomeraci. 
Celý proces je dále ostatními akademickými členy týmu reflektován z hlediska sociologického uvažování o dělnických identitách a sociologie vzpomínání a etnických identit, na neakademické rovině připravujeme výstavy ve veřejném prostoru Brna, Ostravy a Prahy a realizujeme výuku na základních a středních školách. Vedle sledování již existujících pamět’ových stop týkajících se poválečného př́íchodu Romů do českých měst (jako jsou spíše sporadicky existující historické materiály, dobová kinematografie apod.), jsou pro projekt klíčové ony dosud nevypovězené, nebo do veřejného prostoru nevypovězené, vzpomínky obyvatel vybraných městských čtvrtí, jejichž důvěru a zájem se snažíme získat. Aktivizační role autorky projektu a celého projektového týmu je akceptována, průběžně reflektována a podrobována diskusím. Klíčový je přitom veřejný rozměr onoho vzpomínání; pamětníci vědí, že vzpomínky budou použity pro výstavu a v médiích, a pokud s tímto nesouhlasí, nemohou se našeho projektu zúčastnit. Dochází tak k samovýběru těch, kteří jsou ochotni se svým osobním př́iběhem do veřejného prostoru symbolicky vstoupit.

\section{Mikroobčanství v „brněnském Bronxu“ - spor, nebo míjení se?}

Nyní se s pomocí konceptu mikroobčanství pokusím ukázat, jaké jsou rezidentní zájmy obyvatel brněnské čtvrti Bratislavská/Cejl, jak jsou tyto zájmy artikulovány a jak jsou ukotveny v historické době, na kterou se váží. Postupně uvedu citace z vyprávění rezidentů a návštěvníků oblasti a připojím stručný komentář. Na závěr tohoto oddílu všechna vyprávění stručně shrnuji a komentuji z hlediska Centnerova konceptu mikroobčanství (2011).

\section{A od té doby jsem tady}

Přišel jsem ze Slovenska. Pocházím z vesnice Spišské Tomašovce, okres Spišská Nová Ves. Na Slovensku jsem se narodil, pracoval, šel jsem na vojnu a z vojny jsem došel domů. No, po vojně jsem došel v sedmdesátém prvním a nastoupil jsem do práce do takového podniku, kde jsme chodili dělat po celým Československu. Do sedmdesátého čtvrtého roku jsme chodili dělat do Prahy, do Ostravy, do Kolína, do Pardubic. A poslali nás sem do Brna v sedmdesátém pátém, a to jsme dělali tam, jak jsme měli ubytovnu, v Obřanech. A to jsem byl mladej, na zábavy jsme chodili po práci večer, tam jsme se seznámili. V sedmdesátém šestém jsme měli, šestého listopadu sedmdesát šest, svatbu. A od tý doby su tady. (obyvatel Bratislavské, květen 2013)

Vyprávění tohoto dělníka, který se na Bratislavské usadil, protože v Brně získal práci, a v souvislosti s ní pravděpodobně i tentýž byt, ve kterém nyní žije, je velmi př́močaré a prosté. Mnoho poetiky a identitotvorné volby v jeho vzpomínání na příchod do Brna nenacházíme. V tomto se má pozorování shodují s předchozím výzkumem Kateřiny Nedbálkové v dělnických prostředích (Nedbálková 2012). Stěhování za prací není prezentováno jako poetická zkušenost, slovy vypravěče ho doprovází př́iležitost a řízení vnějšími silami spíše než volba. S tím souvisí také artikulace rezidentních zájmů, v tomto případě spíše její absence. Vypravěč šel prostě tam, kde byla práce, kam ho zaměstnavatel přemístil, až to působí tak, že kdyby ho dodnes jeho tehdejší zaměstnavatel posílal po krátkodobých kontraktech, stále ještě by koloval po dělnických ubytovnách. V jeho celém vyprávění se př́liš často neobjevuje hodnocení životních podmínek ve čtvrti Bratislavská/Cejl, ve svém vyprávění nevěnuje žádnou 
pozornost tomu, do jakých podmínek se v Brně kdysi nastěhoval. Prostě dostal byt. Zvykl si. Je tam, kde je, protože tam dostal byt. Takto by se dala shrnout většina vzpomínek na př́chod do České republiky, které jsme v rámci projektu Pamět romských dělniků nashromáždili. Tento př́stup je $\mathrm{v}$ kontrastu $\mathrm{k}$ následující (v pořadí třetí) výpovědi, jež patří obyvatelce, kterou bychom mohli označit za gentrifikátorku (Brožovičová 2013). Nejprve ale věnujme pozornost pasáži z vyprávění, které tematizuje zlom etnizace a vyhrocení sousedských vztahů po roce 1989 .

\section{„Nechceme Romy," do očí nám to říkávala}

Tazatelka: No a když jste se nastěhovali do Brna, tak kde jste bydleli?

Žena: Na Hvězdové jsme bydleli.

Tazatelka: Na Hvězdové jste bydleli dlouho, že jo?

Žena: Ano, ano, celých dlouhých let, tam jsme bydleli.

Muž: Tam jsem bydlel, všecky děti jsem tam vychoval, na Hvězdovej ulici.

Žena: No a potom to převzaly majitelky, samožrejmě a začaly: „Cigáni ven.“ Jó. A když jste neměli dekréty, tak oproti nám, nahoře mladej soused, jo, taky to museli opustit, a nedala nám pokoj zkrátka. A platili jsme poctivě, všechno. „Nechceme Romy,“ do očí nám to říkávala. A: „Cikáni, bordel.“ Přitom já jsem tam umývala chodbu, skoro každý den, to jste neviděla, aby tam byl špendlík na zemi. No, bylo to zbytečný. Chodily ke mně děti na návštěvu, to jí vadilo.

Muž: Ona měla zahradu, omítka na té zahradě, to byla zděná zahrada, to bylo všecko dóle. Za svoje peníze, koupil sem materiál, nahodil sem to, betóny sem udělal, dal sem tam písek, aby si děti mohly tam hrát, lebo nebyly, neměl sem tam jen já děti, i další, Češi tam měli děti. Co byli rádi, že sem to tam udělal. Tam když pršelo, tak bylo vody tak. Odpadové kanály, všecko sem udělal já. My jsme byli špatní pro ni.

Žena: Tolik udělala, že nás z toho bytu vystrnadila. A od tý doby putujeme, putujeme. Rok a půl tady, rok a půl tam, a furt sháníme byty, tady to není dobrý, protože jsou daleko doktoři. Něco se stane, než dojede doktor, přece Bohunice sú dost daleko odsud. Než dojede doktor, nevíme, co se může stát, přece tam je to rychlejší dole. Tak zase sháníme byty, a to je furt takhle. Jsme jak putovníci. (bývalí obyvatelé Hvězdové, listopad 2012)

Manželský pár přistěhovalců za prací, který prožil podstatnou část života na Hvězdové ulici, si stejně jako předchozí mluvčí město ani čtvrt', kde se usadili, nijak zvlášt' nevybíral. V režii manželů ale nebyl ani odchod z Hvězdové. Oba ve vyprávění popisují, jak, každý svými prostředky, přispívali ke zdárnému chodu života $\mathrm{v}$ domě. Paní myla chodbu, pán dělal drobné zednické práce. Oba tak z jejich úhlu pohledu dělali něco dobrého i pro ostatní a vyjadřují bezmoc nad rozhodnutím nových majitelek, že nechtějí v domě Romy. Žena vyjadřuje nevoli majitelky nad tím, že ji chodily navštěvovat děti. Můžeme odhadovat, že je pro ni bolestné, že její vlastní děti se $\mathrm{v}$ očích majitelky změnily prostě na Romy, které $\mathrm{v}$ domě nechce. Žena vyjadřuje bezvýchodnost situace, nemohla nevídat své děti a nemohla už 
chodbu mýt častěji, a navíc, stejně by to nepomohlo. Vidíme zde, jak jejich rezidentní zájmy prohrávají pod tíhou jednoduše vysloveného, a explicitně etnizovaného, rozhodnutí. V jejich vyprávění není známka toho, že by se pokoušeli protestovat, rozhodnutí zvrátit, dovolat se u vnější autority svých zájmů. Kočovníky, kterými nikdy nebyli, z nich učinila až otevřená ekonomika a otevřená sousedská nevraživost. Samozřejmě že pro komplexní posouzení situace zde chybí vyprávění oné majitelky. Pro demonstraci dalšího z rezidentních zájmů to však domnívám se postačuje. Je to zájem nesdílet obytný dům s Romy a vyjádřená rezignovaná pasivita na straně těch, kteří jsou označeni jako rezident non grata.

\section{Že to vlastně ráda pozoruji}

Pro mě to bylo důležité, protože to bylo kousek do centra města. Bydlení je tam vlastně hezké a mě to nepřipadlo jako negativum, to, že žiju v takovéhle [ehm] komunitě nebo v takovéhle čtvrti, nýbrž mi to přišlo něčím pestré, že to vlastně ráda pozoruji. Strach jsem neměla, protože jsem do té doby neměla žádné negativní zkušenosti, navíc doted' nemám, musím to zaklepat, takže jsem se nebála a byt jsem si tam koupila. Já jsem žila poměrně aktivně společenský život a nemyslela jsem na rizika, neměla jsem děti, nebo něco takového, ani strach. Prostě jsme pařili a nebyl prostě nějak důvod se tak strašně všeho bát. (obyvatelka Hvězdové, duben 2013)

Vyprávění této etnomajoritní obyvatelky gentrifikátorky ukazuje, jak vnímá svou volbu přestěhovat se do oblasti Bratislavská/Cejl jako životněstylové a estetické rozhodnutí. Lehce slovy krouží kolem problematiky romských obyvatel, možného rizika, které s tím pro ni, coby př́slušnici etnomajority, může vyplývat, rámuje romské obyvatele jako zpestřující folklor, který ji může vytrhávat z případné nudy. Toto vyprávění dobře vystihuje určitý typ obyvatel zchátralých částí historických měst v Evropě, jak je popisuje na př́ikladu Gdaňsku Maja Grabkowska (2011). Byty ve čtvrtích se silnou historickou stopou, v případě střední Evropy z doby předkomunistické, pěší dostupnost centra a určitá nekonvenčnost lákají kosmopolitně uvažující lidi, kteří nežijí rodinným životem. Uzpůsobují si pak polozchátralé byty s vysokými stropy svým potřebám a každý den se, když z domu pěšky kráčí do své oblíbené kavárny v centru města, utvrzují, že jsou tam, kde mají být. Jaký je rezidentní zájem této obyvatelky? Ve zkratce bych ho nazvala žít někde, kde to má esprit (Bell a de-Shalit 2011) odpovídající mému já, aby mne mé bydlení, trochu odvážné, trochu nedbalé a strategicky vhodně zvolené, doplňovalo v působení dovnitř, pro mne samotnou, i navenek pro ostatní. Vysoce ceněným měřítkem je pak, vedle finanční dostupnosti, estetizace vlastního bydlení i života. K dosažení takového cíle slouží domy, ulice, ale také ostatní obyvatelé jen jako pasivní kulisa.

\section{Cikáni, nehanbíte sa?}

Jenom řeknu jednu věc k tomu, jak se to měnilo. Já když jsem dělal na Úřadě práce na Křenové, tak tam tehdy byl vedoucí můj kamarád a on mě požádal, abych přišel vždycky nějaký den na Bratislavskou a mluvil na ty děcka. On tam dělal besedy. A já jsem za nima chodil, za těma děckama, učil jsem je třeba kreslit nebo jsem jim vykládal, jak já jsem chodil do školy a podobně. 
A když jsem šel na ten dvůr, do toho jako by areálu pavlačí, ${ }^{9}$ tak tam v té době byla od poschodí až dolů hromada svinstva. To tam se jim nechtělo chodit někde do popelnic, tak to sypali z toho vrchu dolů a ze spodu to tam házeli. A já, když jsem tam došel za těma děckama, tak jsem šel na ten dvůr a viděl jsem to; a ted' jsem viděl, jak tam lezou potkani a myši a všecko možné a smrad. A protože já jsem byl už na tom Úřadě práce a měl jsem jakýsi jejich respekt, tak jsem se postavil uprostřed toho dvora a začal jsem křičet. „Romále, nalad’ám tumen?“ Jakoby když řeknu „Cikáni, nehanbíte sa?“ A ted’ oni vylezli ven a oni někteř́: „,Jé, pan Zíma, dobrý den pán Zíma,“ protože nemohli si dovolit se mnou se nějak moc hádat. A já říkám: „A co to to tady děláte, s tímto? To se nebojíte, že vás sežerou ty potkani?““ „No šak to tam ten, to tam ten.“ A pak říkám: „A to vy neumíte uklidit?“ Tak oni zas někteří to nemohli snést, že jim vytýkám, tak někteří na mě hned jako reagovali: „Však kdeby nám dali lopaty““ A já ř́kám: „Jó? Tak já tady vezmu love, peníze, a půjdu vám koupit deset lopat a ještě vám je podám do ruky a ještě budete chtět, abych vám pomáhal s tou lopatou hýbat, ne.“ Tak oni se smáli. No a tak se dosáhlo toho, že jsme dělali tlak, ted' jsem získával ještě nějaké další tam odsud' a ted' ještě ty děcka, protože byly dost, pořád se bily, jo. A já nevím co. Ty rodiny se tam mezi sebou hádaly, jeden přes druhého křičeli, přes pavlač, a postupně. A v čem vidím tu změnu. Ty děcka, když tam šel nějaký cizí člověk: „Dej mně cukrové, dej mně cigaretu, dej mně peníze. A, co tady děláš, co tady hledáš?" Jo, a takhle. No a aji do kapes hned šli. A dneska, když bych tam šel, nebo kdokoliv jiný, tak už: „Pane Zima, dobrý den, jak se máte?“ Ty děcka. (Ignác Zima, červen 2012)

Bývalý zaměstnanec brněnského Úřadu práce Ignác Zima je jedním z průkopníků porevolučních romských integračních programů v Brně, ale také bývalým aktivistou ve Svazu Cikánů-Romů na Moravě. Na Bratislavské nikdy nebydlel, ale vždy tam, z profesních i osobních důvodů, docházel. Jeho zájem můžeme nazvat zájmem o slušnost a čistotu na ulici. Něco, co by jistě sdílel s mnoha obyvateli oblasti Bratislavská/Cejl, bez ohledu na etnickou příslušnost. Jeho vyprávění je zajímavé tím, že se osobně angažoval ve vyjednávání zlepšení stavu, využíval svou autoritu, ale také osobní vazby ve vyjednávání změny. Právě tento kontakt a př́má konfrontace vyjednávání je nejvýraznějším projevem mikroobčanství, který předkládaná vyprávění demonstrují. Přesto i ostatní příklady slouží jako cenný podklad pro uvažování o povaze sousedských vztahů v Brně na Bratislavské/Cejlu a česko-romských vztahů v české společnosti obecně.

Na př́kladu hodnocení bydlení v brněnské oblasti Bratislavská/Cejl jejich rezidenty a návštěvníky jsem ukázala proměnu zájmů obyvatel v čase, přičemž je možné tuto změnu uvést do časové souvislosti s poválečnou industriální rekonstrukcí, demokratizačními změnami a na čtvrt' postupně dopadajícím úpadkem sousedské kultury a životní úrovně bývalých dělnických rodin. Zároveň je možné si všimnout rozdílného vnímání a rozdílných zájmů obyvatel čtvrti s romským etnokulturním pozadím a těch, kteří jsou ukotveni v etnomajoritní kultuře. V tabulce stručně shrnuji představené rezidentní zájmy.

Jedná se o komplex domů spojených velkým pavlačovým dvorem na Bratislavské 41, kde dnes sídlí občanské sdružení DROM. 
Tabulka 1: Rezidentní zájmy obyvatel a uživatelů čtvrti Bratislavská/Cejl

\begin{tabular}{|l|l|l|l|}
\hline Období & $\begin{array}{l}\text { Etnický Čech / } \\
\text { Český Rom }\end{array}$ & Zájem & Poznámka \\
\hline 50. léta & ČR & $\begin{array}{l}\text { Pragmatické propojení } \\
\text { práce a bydlení }\end{array}$ & Zdánlivá nevýběrovost a nenárokovost \\
\hline 90. léta & EČ & Nemít v domě Romy & $\begin{array}{l}\text { Dle vyprávění romského obyvatele } \\
\text { de facto bez uznání dalšího kontextu }\end{array}$ \\
\hline 2000 & EČ & Esprit & $\begin{array}{l}\text { Estetizace čtvrti, estetizace vlastního života } \\
\text { gentrifikátorú }\end{array}$ \\
\hline 2000 & ČR & Slušnost na ulici & Osobně vyjednávaná \\
\hline
\end{tabular}

Především je z vyprávění rezidentů a návštěvníků patrné, že obě pomyslné strany, čeští Romové a etnomajoritní obyvatelé čtvrti, spolu v současné době nepřichází příliš často do osobního kontaktu. Aby bylo možné o tomto více vypovědět, museli bychom se do oblasti ponořit komplexnějším etnografickým zkoumáním. Každopádně je toto pracovní zjištění v kontrastu s Centnerovým představením mikroobčanství. Zdá se, že různí rezidenti o čtvrt' nevyjednávají, prostě se navzájem vyhýbají, a zdá se, že zvláště v případě etnomajoritních obyvatel na ty druhé nadávají. Může to značit velkou vzájemnou nedůvěru, ale také prostě občanskou pasivitu a nedůvěru ve smysluplnost takového vyjednávání. Problémy s chátráním domů a neprrívětivým pouličním klimatem jistě pocit’ují všichni obyvatelé čtvrti, ale to jim patrně nedává dostatečně velkou motivaci k tomu, aby spolupracovali k nalezení řešení směrem k lepšímu bydlení pro všechny. Znovu se tak dostáváme k otázce legitimity existence Romů v české společnosti. Etnomajoritní obyvatelé jako by ani nechtěli hledat řešení pro všechny a netrpělivě vyhlíželi řešení, jak žít bez těch druhých. Pasivita a smířenost, s jakými Romové tuto atmosféru snášejí, stejně jako strach z Romů a odpor k nim v př́padě etnomajoritních obyvatel, jsou, jakkoliv je to lidsky tragické, hodny další výzkumné pozornosti a tato malá sonda na hlubší objasnění nestačí. Nyní ještě pro dokreslení mapy „brněnského Bronxu“ obrat'me pozornost k místům paměti Bratislavské/Cejlu, která atmosféru, v níž rezidenti žijí svou každodennost, spoluvytváríi.

\section{Místa paměti v „brněnském Bronxu“ - vzkaz budoucím generacím}

Smysl míst paměti nespatřuje Pierre Nora pouze v jejich materiální existenci; musí podle něj také být nabita symbolickým významem a mít nějakou funkci. Teprve v této trojjedinosti je možné místům paměti porozumět. V materiálním prostoru městské části Bratislavská/Cejl vybírám dvě místa paměti, která nejprve definuji materiálně, abych dále ukázala jejich symbolický a funkční význam pro politiku paměti. Prvním je tato oblast jako celek a její literární ztvárnění v románu Kateřiny Tučkové Vyhnání Gerty Schnirch (2009), druhým pamětní deska romského holocaustu instalovaná na ulici Masná, která byla přemístěna do Muzea romské kultury. Pierre Nora stanovuje jako podmínku existence míst paměti vzájemně podpůrnou hru paměti a historie (1998: 24). V obou případech tato hra poměrně explicitně ožívá a soustředí se kolem událostí druhé světové války, zároveň se jedná o historické události, jejichž interpretace není u české laické ani odborné veřejnosti nijak ustálena. Jedním z důvodů je, domnívám se, rozpačitá a nevyjasněná pozice Romů v českém mýtotvorném př́běhu. 


\section{Gerta a Cikáni}

Spisovatelka Kateřina Tučková ve svém románu Vyhnání Gerty Schnirch (2009) vykresluje Brno první poloviny 20. století, přičemž velkou pozornost věnuje explicitnímu zviditelňování německé stopy v prostoru centrálního Brna. Román, především v osobě hlavní postavy, symbolizuje osobní příběhy obětí vyhnání brněnských Němců v květnu 1945 a plní funkci narovnávání historických křivd ve smyslu artikulace tabuizovaných traumat. Hlavní hrdinka žije na ulici Hvězdová, stěžejní pro román je tak právě oblast Bratislavská/Cejl. Zajímalo mě, za jakých okolností a pohnutek román vznikal, a tak jsem v dubnu 2013 požádala autorku o rozhovor. Jedním z impulzů k napsání románu bylo podle Tučkové pozorování jakési kulturní ruptury, kterou autorka vnímala při procházení čtvrtí poté, co se do ní přestěhovala:

Tučková: To úplně první, čeho jsem si tam všimla, bylo, že když jdu po Bratislavské, tak jako historička umění vidím krásné klasicistní a secesní domy, které jsou ale ve strašlivém stavu. Navíc je to nějaké divné - proč v takových krásných domech bydlí Romové a sociálně slabí? Celé mi to prrišlo záhadné, dokud jsem si nevšimla i německých nápisů na loupajících se fasádách, zavrtaných kulek a tak. Tak takhle jsem přemýšlela.

Tazatelka: Proč je to divné?

Tučková: Jakým zpo̊sobem by se lidé, kteři žili kočovným způsobem života, dostali do nádherných secesních baráků? Tady muselo proběhnout něco, o čem jsem nevěděla přesně co. Došlo mi, že to, co je vidět dnes, je jen důsledek, který odpovídá něčemu, co se stalo v minulosti. Jako literátka jsem v tom zavětřila zajímavý prŕběh, po kterém jsem pak šla. (Kateřina Tučková, duben 2013)

Na autorčině vyprávění mne zaujalo, že ačkoli ví, že se jedná o pravděpodobně historicky neadekvátní zkratku, hovoří o Romech jako o lidech s kočovným způsobem života. Jakoby historická neadekvátnost $\mathrm{v}$ tomto případě nebyla př́iliš důležitá, stejně jako celá romská linie př́iběhu brněnské oblasti Bratislavská/Cejl. Postupně při práci na románu získali v textu reprezentanti všech relevantních etnokulturních skupin (české, německé, rakouské, židovské) alespoň jeden osobní příběh, až na linku romskou. Ta zůstává ve formě doplnění, stereotypně pojatého odstínu. Sama autorka to vysvětluje především literární pragmatikou:

Chtěla jsem ukázat, jak se člověk dostane do spárů velké historie, jak se to s ním vlastně otáčí a on může jen bezmocně přihlížet. A soustředila jsem se přitom na problematiku česko-německou. V této otázce byla romská problematika jenom malinký stř́pek mozaiky toho, jak se proměnilo místo, ve kterém žila Gerta Schnirch. Proto jsem se romské otázce v románu nijak zvlášt' nevěnovala. (Kateřina Tučková, duben 2013)

Autorka přiznává, že skutečně neměla ambici tuto linii příběhu pojednat skrze osobní příběh. Jak jsem již ale zmínila, je to $\mathrm{v}$ kontrastu s literárními strategiemi, které zvolila k ostatním etnokulturním stopám meziválečného a poválečného Brna, a $\mathrm{k}$ tomu, že to byli romští obyvatelé, kteři představovali impuls $\mathrm{k}$ pátrání po detailním příběhu této brněnské čtvrti. Dvě „romské“ zmínky patří v románu obyvatelům Bratislavské/Cejlu po roce 1945 (Tučková 2009: 239-240, 369), jedna pak Romům obecně, kdy upomíná na jejich pejorativní vnímání majoritou (Tučková 2009: 327-328). Pro ukázku zde přikládám nejobsáhlejší ze tří románových pasáží: 
Pressburger Straße, ted' už jen Bratislavská, s přilehlými ulicemi se v prvních dnech po válce zaplnila novými českými obyvateli a ted', o šest let později, se postupně zaplňovala cikány z okolí i ze Slovenska, které chtě nechtě v nějakém šíleném sociálním plánu usazovali sem, do opuštěných bytů, ze kterých jejich krátkodobí držitelé utekli do nově stavěných sídlišst'. Ne všichni, samozřjejmě, byli i takoví, které ani poválečný vítr neodvál. (Tučková 2009: 239-240)

Autorka sama vysvětluje, jak ke své strategii literárního ztvárňování romské stopy v oblasti dochází, dvěma důvody: pragmatismem při editování příběhu (vše se do románu prostě vejít nemůže) a odrážením způsobu, jakým o Romech v oblasti hovoří starousedlíci. Že i mezi romskými obyvateli Bratislavské/Cejlu jsou starousedlíci, to zůstává Kateřině Tučkové i její Gertě Schnirch zastřeno. S Tučkovou jsme také hovořily na téma volby jazykového označování Romů jako „cikánů“. Důvodem bylo především přiblížení se jazykovému úzu neromských starousedlíků. K výše uvedené citaci Tučková dodává:

Tohle mi sdělil pán, který žije na Soudní nebo Přadlácké, zkrátka v jedné z těch bočních ulic, které jsou ale $\mathrm{v}$ této čtvrti. Když jsem se $\mathrm{s}$ ním setkala, vykládal mi, že tam je od třicátých let, a načrtl mi proměnu té čtvrti. Tedy to, že odtamtud nejprve byli v květnu 1945 v divokém odsunu vyhnáni brněnští Němci, pak tam přišli dělníci ze Zbrojovky, kteří si obsazovali hezké a plně vybavené byty, ale kteři prý potom brzy odešli do nově vybudovaných sídlišt' a továrních bytů. Podle jeho vyprávění se to stalo v padesátých letech, kdy byli zároveň usazováni kočovní Romové, a proto na Bratislavskou přišla ta první romská vlna. Nejhorší proměnu té čtvrti ale zaznamenal na začátku 90. let, kdy za usazenými Romy začali přicházet př́buzní ze Slovenska. (Kateřina Tučková, duben 2013)

Román Vyhnání Gerty Schnirch není jediným př́ípadem ze současné, k etnizovaným traumatům 20. století citlivé, literární produkce, kde se Romové v jinak adresných vyprávěních objevují coby bezejmenná skupina narušitelů. Alena Wagnerová sebrala a literárně upravila vzpomínky sudetských Čechů, které vydala pod názvem Neodsunuté vzpomínky. Česká zkušenost pohraniči (2000). V knize o 241 stranách najdeme jen dvě zmínky o Romech, obě neadresné. Jedna pojednává o mostku, pod kterým Cikáni přespávali (2000: 167), jedna shrnuje názor mluvčího na jejich příchod:

A ještě jedna věc. Němci byli pracovití lidé. A místo nich jsou ted' v severních Čechách cikáni. A ti republiku nebudují. (2000: 34)

Zde se, kromě neosobního, neadresného přístupu, zhmotňuje dojem z neparticipování, a tudíž nenáležení do mezního společenství české společnosti ústřední solidarity (Alexander 1988). Úkolem literárních zpracování dějinných událostí není takové spory rozsuzovat. Z hlediska ustanovování způsobů, jakým Romové ne/patří do prostoru českých měst a míst však můžeme vidět určitou tendenci neadresného reprodukování anonymní a ne př́liš pozitivní zkušenosti z kontaktu s nimi. Romští obyvatelé jsou v literatuře a vzpomínkách (implicite) neromských obyvatel líčeni jako bezejmenné postavy, objekty historie, která je plná omylů a ubližování. Žádný z nich nemá jméno, osobní příběh. To je ve velkém kontrastu k reprezentantům ostatních etnických skupin a to, že to výše zmíněné autorky, které obě nepostrádají ve svém literárním projevu sociální citlivost k tragédii individuálního lidského osudu, nevnímají jako nelegitimní, je ukázkou symbolické marginalizace Romů v současné české 
společnosti skrze politiku paměti. Tato marginalizace má také svůj žitý, všednodenní rozměr. To, že autorka Vyhnání Gerty Schnirch nenašla v průběhu psaní svého románu cestu k, byt' letmému, rozhovoru s některou z romsky vypadajících babiček a dědečků v oblasti, kterou popisuje, poukazuje na to, že to nejsou jen cesty českých a německých obyvatel, které byly kdysi ve všedním životě Brna rozděleny. Dnes jako by kolem sebe obloukem chodili etničtí Češi a čeští Romové a míjeli se, byt' spolu ulice, tramvaje a vchody domů mnohdy sdílejí. $\mathrm{Na}$ dvou př́kladech současné literární produkce jsem chtěla ukázat, jak místa romské paměti v České republice zůstávají mimo hledáček etnomajoritního vyprávění příběhu českých měst, a to včetně jejich pohnuté válečné historie, prričemž toto míjení se a jen letmé neadresné dotýkání se těchto osudů se zdají být, jak ukazuje reflexe vlastní tvorby autorky románu Vyhnání Gerty Schnirch, dostačující a legitimní. Tato symbolika neadresnosti romských př́iběhů je pak, domnívám se, spíše nezamýšlenou funkcí reprodukce marginálního postavení Romů, postavení mimo českou společnost ústřední solidarity.

\section{Patřičné místo upomínky na 999 mužů, žen a dětí}

Druhé místo paměti je místem pohyblivým, přičemž pohyb sám zde má významnou symbolickou funkci. Jedná se o pietní místo upomínající na násilné soustředění 999 moravských Romů za účelem transportu do vyhlazovacího tábora v Osvětimi. Na události z března 1943 upomínala od roku 2000 pamětní deska, která byla umístěna na fasádu komplexu budov na ulici Masná, kde sídlila protektorátní policie a odkud byli moravští Romové do tábora v Osvětimi transportováni. Ulice Masná se nachází cca dva kilometry jižně od oblasti Bratislavská/Cejl, jedná se také o vnitřní část Brna, která v posledních letech prochází gentrifikací. ${ }^{10}$ Deska zde byla umístěna ze společné iniciativy historika Ctibora Nečase, který se dlouhodobě zabývá dějinami Romů na českém území, Muzea romské kultury a Muzea města Brna. V roce 2003 byl celý areál na Masné zbourán a dříve městské pozemky byly prodány do soukromých rukou. Na místě vznikla vícečetná vlastnická struktura, se kterou se Muzeum romské kultury pokusilo vyjednat souhlas s umístěním desky na některý z nově postavených domů. Žádost však byla zamítnuta s tím, že si obyvatelé nepřejí být obtěžováni touto upomínkou. Nastalo stěhování pamětní desky do Muzea romské kultury, kde je nyní vystavena ve stálé expozici Cesty Romů v oddělení upomínajícím na romský holocaust a každoročně se zde koná pietní akt. ${ }^{11}$

10 Události na Masné připomínají negativní vlivy gentrifikačních procesů na nízkopříjmové obyvatele městských čtvrtí, o kterých se v sociologii města diskutuje (Centner 2011); je-li chudoba etnizována, procesy se ještě posilují (Blokland 2009). Gentrifikace, ve smyslu zvelebování zchátralých částí měst, se tak v př́ípadě oblasti Bratislavská/Cejl i Masná ukázala být skutečně problematickou, pokud se její součástí jaksi mimochodem stává vytrácení stigmatizované etnické stopy paměti míst. Otázkou je, zda by deska nemohla být stejně tak, nebo lépe, umístěna v místnosti upomínající na vývoj česko-romských vztahů po roce 1989. V tomto oddělení je porevoluční vývoj představen s pomocí novinových titulků upomínajících na nejrůznější mediálně pokryté události, především pak nejrůznější etnizované česko-romské konfliktní kauzy, a mohl by se zde každoročně konat pietní akt upomínající na to, že česko-romské vztahy dosud nenalezly občansky neproblematickou podobu. 
Příběh stěhování pomníku romského holocaustu z ulice Masná jde významově dále, za pouhou nevšímavost $\mathrm{k}$ individuálním stopám romských obyvatel, které zanechávají v materiálním a symbolickém prostoru České republiky. Odpor $\mathrm{k}$ reinstalaci pomníku na místě, kde dř́íve stály budovy, jež byly s pietními událostmi bezprostředně spjaty, je přímo aktivním vymazáváním obtěžujících, nežádoucích stop z paměti města Brna.

Iniciátoři původní instalace desky se podvolili nevůli nových majitelů pozemků a obyvatel nových budov a desku umístili do jiného kontextu, ve kterém nevyvolává averze obyvatel a kolemjdoucích. Tím místem, které symbolizuje patřičné umístění paměti, je stálá expozice v Muzeu romské kultury. Etnizovaná pamět' se tak přestěhovala do etnizované veřejné instituce, aby nenarušovala implicitně etnomajoritní řád běžné brněnské ulice. Deska tedy nadále plní
Foto 1: Pamětní deska deportací Romů z Brna položená ve stálé expozici MRK v místnosti věnované holocaustu Romů

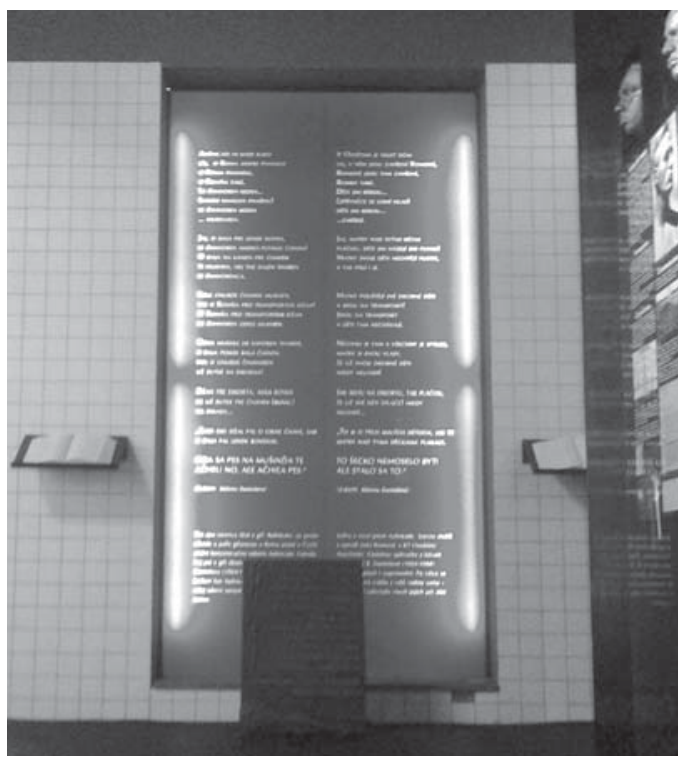

Zdroj: Autorka svou pietní funkci, ale změnila se její symbolická hodnota. Zatímco před rokem 2003 symbolizovala náležení událostí romského holocaustu do veřejného prostoru České republiky, nyní upomíná na legitimitu připomínání těchto událostí, ovšem jen v explicitně etnizovaném prostoru Muzea romské kultury. Umístěním desky v expozici holocaustu bez komentáŕe, co tam deska vlastně dělá, se navíc symbolicky vytrácí a znevýznamňuje konfliktní rovina vyjednávání expozice desky a jejího stěhování, událost stěhování desky je tak po letech známa pouze specialistům, kteří se o danou kapitolu českých dějin blíže zajímají, a symbolický význam tohoto konfliktního vyjednávání místa paměti se vytrácí.

Na ukázkách anonymní prezentace Romů v literatuře tematizující etnizované utrpení na území dnešní České republiky v období druhé světové války a vyjednávání expozice pomníku romských obětí druhé světové války v Brně jsem ukázala, jak místa paměti, která nesou explicitní romskou stopu, jsou bud' znevýznamňována, nebo rovnou přemístována mimo všeobecný, neetnizovaný veřejný prostor. Symbolicky toto naznačuje a funkčně podporuje nedůležitost nebo nelegitimitu existence romské stopy v českém veřejném prostoru. Předchozí analýza může poukazovat na to, jak se český veřejný prostor na jednu stranu jeví jako etno-neutrální, je však spíše charakteru etnomajoritního. To možná samo o sobě nemusí být problém, problémem ale je, pokud je toto nereflektivně do veřejného prostoru podsouváno a není-li to veřejně diskutováno. Ostatně, při čtení sociologických prací zabývajících se pamětí musí čtenář nabýt dojmu, že více než reflexi a stále pokračující diskusi si v oblasti politiky paměti ani slibovat nemůžeme. 


\section{Závěr}

Sociolog Jiří Šubrt upozorn̆uje ve své teoretické stati na nevyhnutelnost plurality sociálních pamětí:

Ostatně v žádné komplexnější společnosti neexistuje jedna kolektivní pamět', ale vždy pluralita kolektivních pamětí. (Šubrt 2011: 150)

Přestože by se zdálo, že přiznáním plurality pamětí se moderní společnosti vypořádají se svými vnitřními diverzitami, samotné uznání různosti nemusí stačit. Ukázala jsem, jak v prostoru brněnské oblasti Bratislavská/Cejl, která nese lidový název „,brněnský Bronx“, spolu v konfliktním a znepokojivě izolovaném vztahu žijí nejen obyvatelé, ale také percepce sousedského prostoru; jak problematický je etnizovaný vztah sousedi̊, kteří mezi sebou rozlišují na české, etnomajoritní, a romské, etnominoritní (z představených narativ vyplývá, že především reprezentanti etnomajority tematizují ty druhé). Toto se projevuje také na úrovni zacházení se vzpomínkami, kdy romští pamětníci př́íchodu do Brna v souvislosti s pracovními příležitostmi v období poválečné reindustrializace Československa nevnímají tento prostor jako životní prostor daný volbou, a už vůbec ne prostor identitotvorný. Jejich pojetí proměn prostoru v čase je dosti odlišné od pojetí etnomajoritních obyvatel a jsou ve svých projevech defétističtí k vývoji událostí v jejich neprospěch. Centner ve svém textu kriticky hodnotí to, že navzdory neoliberální ideologii, jejíž součástí je tlak na zvýšení inkluzivního potenciálu společnosti, setkáváme se s

vysoce prostorově a časově ohraničenými, vratkými a velmi zlomkovitými formami přináležení k městu. (Centner 2011: 19)

Taková je i pamět' oblasti Bratislavská/Cejl, zlomkovitá a odrážející partikulární zájmy jednotlivých obyvatel a uživatelů čtvrti. Na rozdíl od Centnerových chudých prodavaček domácích koláčů, které si uhájily své místo a obživu v Buenos Aires (2011), Romové na Bratislavské/Cejlu, soudě podle vyprávění pamětníků, odpovídají svým chováním ve veřejném prostoru spíše popisu Talji Blokland (2009), která ukazuje, jak černošští obyvatelé New Havenu o svou pozici ve veřejném prostoru př́liš nebojují, a pokud ano, tak neúspěšně nebo bez všeobecně uznaných a viditelných výsledků. $\mathrm{Na}$ prríkladech neadresného literárního zachycení romské stopy v prostoru „,brněnského Bronxu“ a putování pamětní desky transportu moravských Romů do koncentračního tábora můžeme pozorovat symbolickou reprodukci sociálně marginalizovaného postavení Romů v české společnosti, stejně jako vytlačování romské pamět'ové stopy z obecného veřejného prostoru (ulice Masná) do prostoru etnizovaného (Muzeum romské kultury).

Přesto existují projevy prolínání žité zkušenosti a upomínání, jakým je malý netrvanlivý pomník, na který mne při společné procházce po Francouzské upozornil v dubnu 2013 historik Muzea romské kultury Michal Schuster (k místu nás spolu s architektem připravovaných projektových výstav zavedl, aby nám tento, jeho slovy „street art“, ukázal). V jednom z pavlačových dvorů je na OSB desce, která přikrývá okýnko do sklepa nebo sítový přivaděč ve dvoře pavlačového domu, vyveden v bílé a zelené kř́idě nápis: „Jen tři slova v srdci měj, miluj, trp a odpouštěj. “"12

12 Nápis je sotva viditelný, proto jej fotografie nezachycuje. 
Jedná se o lidový slogan, který měla v památníku vepsaný spolu s kresbou pastelkami snad každá dívka mé generace. Nápisu lze rozumět jako jakési upomínce společného žití-nežití na Bratislavské/Cejlu. Je zde jen pro místní a zasvěcené, nevedou $\mathrm{k}$ němu ukazatele městského informačního systému a velmi pravděpodobně nepřežije jednu zimu. Přesto je důležitý, protože ukazuje, že komunikace ve veřejném prostoru a o veřejný prostor $\mathrm{v}$,brněnském Bronxu“ neustává. Horší než spory o pamětovou stopu a identitu místa může být totiž mlčení.

Kdo tedy kreslí mapu „brněnského Bronxu“? Jsou to pamětníci
Foto 2: OSB deska s nápisem křídou na Francouzské, duben 2013

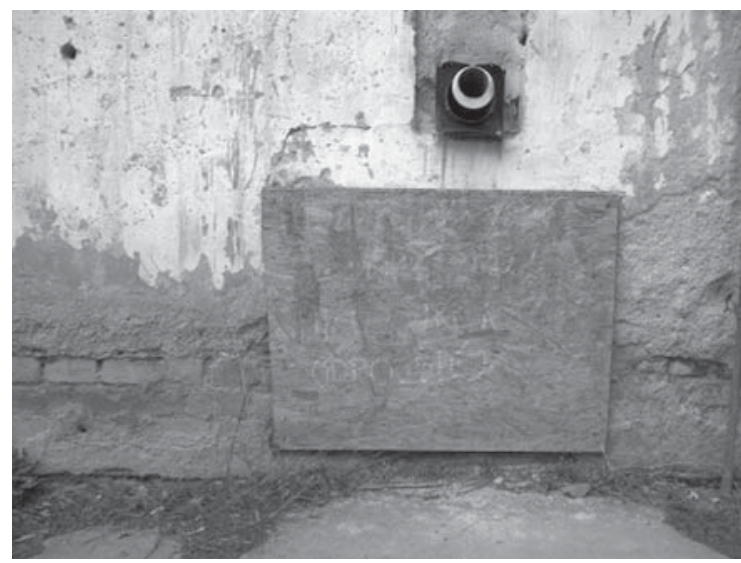

Zdroj: Autorka a současní obyvatelé místa, také urbanisté a zástupci veřejné správy, kteří rozhodují o investicích do veřejného prostoru, stejně jako spádovosti škol či rozmístění placených parkovacích zón, odpadkových košůu, laviček a služeben městské policie. Jsou to však také uživatelé pojmu „,brněnský Bronx“, média, organizátoři kulturních akcí či street artoví umělci. V neposlední řadě jsou to také čtenáŕi textů o „brněnském Bronxu“, včetně čtenářů tohoto textu, a čtenáři ulic, když po nich jdou a mísí se na prašných úzkých chodnících s ostatními kolemjdoucími a místními obyvateli.

Cílem však není pamět’ a identitu místa, v tomto př́ípadě jedné oblasti Brna, uzavřít, rozhřešit, zakonzervovat. Jak píše Edward Said,

umění paměti je v moderním světě pro historiky, stejně jako pro běžné občany a instituce, především něčím $\mathrm{k}$ uživání, zneuživání a vykořistování, spíše než něčím, co by nehybně leželo a čekalo, až to každý člověk uzme a obsáhne. (Said 2000: 179)

V tomto duchu je tento text pouze navazujícím vláknem nekončícího diskurzivního dialogického souboje o identitu jednoho místa, a tím také obecně o povahu alexandrovské společnostní komunity.

\section{Literatura}

ALEXANDER, Jeffrey. Core Solidarity, Ethnic Outgroup, and Social Differentiation. In ALEXANDER, Jeffrey. Action and its Environments. Toward a New Synthesis. New York: Columbia University Press, 1988, s. 78-106. ISBN 0231062095.

BAUBÖCK, Rainer. Sharing History and Future? Time Horizons of Democratic Membership in an Age of Migration. Constellations, 1998, roč. 4, č. 3, s. 320-345. ISSN 1467-8675. 
BAUMAN, Zygmunt. Globalizace: dissledky pro člověka. Praha: Mladá fronta, 2000. ISBN 8020408177. BELL, Daniel A. a Avner DE-SHALIT. The Spirit of Cities: Why the Identity of a City Matters in a Global Age. Princeton: Princeton University Press, 2011. ISBN 9780691151441.

BIRD-DAVID, Nurit. No Past, No Present: A Critical-Nayaka Perspective on Cultural Remembering. American Ethnologist, 2004, roč. 31, č. 3, s. 406-421. ISSN 1548-1425.

BLOKLAND, Talja. Bricks, Mortar, Memories: Neighbourhood and Networks in Collective Acts of Remembering. International Journal of Urban and Regional Research, 2001, roč. 25, č. 2, s. 268-283. ISSN 1468-2427.

BLOKLAND, Talja. Urban bonds. Cambridge: Polity Press, 2003. ISBN 0745628028.

BLOKLAND, Talja. Celebrating Local Histories and Defining Neighbourhood Communities: Place-making in a Gentrified Neighbourhood. Urban Studies, 2009, roč. 46, č. 8, s. 1593-1610. ISSN 1360-063X.

BROŽOVIČOVÁ, Klára. Gentrifikace: Přiležitost integrace? Připadová studie lokality Brno Zábrdovice. Brno, 2013. Diplomová práce. Masarykova univerzita, Fakulta sociálních studií, Katedra sociologie.

BRÜHL, Hasso, Claus-Peter ECHTER, Franciska FRÖLICH VON BODELSCHWINGH a Gregor JEKEL. Wohnen in der Innenstadt - eine Renaissance? Berlin: Deutches Institut für Urbanistik, 2005. ISBN 978-3-88118-392-5.

CENTNER, Ryan. Microcitizenships: Fractious Forms of Urban Belonging after Neoliberalism. International Journal of Urban and Regional Research, 2011, roč. 10, č. 111, s. 1-27. ISSN 1468-2427.

DUANY, Andres a Elizabeth PLATER-ZYBERK. The Neighborhood, the District, and the Corridor. In KATZ, Peter a Vincent SCULLY, Jr. (eds.). The New Urbanism: Toward Davan Architecture of Community. New York: McGraw-Hill Professional Publishing, 1993. ISBN 0070338892.

FABIAN, Johannes. Time and the Other: How Anthropology Makes Its Object. New York: Columbia University Press, 1983. ISBN 0231125771.

GLYNN, Irial a J. Olaf KLEIST. History, Memory and Migraiton: Comparisons, Challenges and Outlooks. In GLYNN, Irial a J. Olaf KLEIST (eds.). History, Memory and Migration. Perceptions of the Past and the Politics of Incorporation. Macmillan: Palgrave, 2012, s. 237-243. ISBN 9780230293380.

GRABKOWSKA, Maja. Flexible Households, Flexible Dwellings, Flexible Neighbourhoods? In HAASE, Annegret, Annett STEINFÜHRER, Sigrun KABISH, Katrin GROSSMANN a Ray HALL (eds.). Residential Change and Demographic Challenge. The Inner City of East Central Europe in the 21st Century. Surrey: Ashgate, 2011, s. 233-253. ISBN 9780754679349.

HAASE, Annegret, Annett STEINFÜHRER, Sigrun KABISH, Katrin GROSSMANN a Ray HALL (eds.). Residential Change and Demographic Challenge. The Inner City of East Central Europe in the 21st Century. Surrey: Ashgate, 2011. ISBN 9780754679349.

HAVELKA, Miloš. Pamět’ a dějiny. In WAGNEROVÁ, Alena. Neodsunuté vzpomínky. Česká zkušenost pohraniči. Praha: Prostor, 2000, s. 227-233. ISBN 8072600451.

JAKOUBEK, Marek. Přemyšlení (rethinking) „Romư“ aneb „Chudoba ,Romů“ “ má povahu Janusovy tváře. In HIRT, Tomáš a Marek JAKOUBEK (eds.). Romové v osidlech sociálního vyloučení. Plzeň: Aleš Čeněk, 2006, s. 322-400. ISBN 8086898768.

LÖW, Martina. The Constitution of Space: The Structuration of Spaces Through the Simultaneity of Effect and Perception. European Journal of Social Theory, 2008, roč. 11, č. 1, s. 25-49. ISSN 1461-7137.

LÖW, Martina. The Intrinsic Logic of Cities. Towards a New Theory of Urbanism. Urban Research \& Practice, 2012, roč. 5, č. 3, s. 303-315. ISSN 1753-5069.

LÖW, Martina. In the Name of Public Interest? How to Design Commons Today. Veřejná přednáška. 10. dubna 2013, Brno: Masarykova univerzita, Fakulta sociálních studií, Katedra sociologie. 
MARADA, Radim. Od Marxe k Alexanderovi. Občanská inkluze jako problém moderní společnosti. In MARADA, Radim (ed.). Etnická různorodost a občanská jednota. Brno: Centrum pro studium demokracie a kultury, 2006, s. 72-114. ISBN 80-7325-111-6.

NEDBÁLKOVÁ, Kateřina. Tak daleko, tak blízko: Dělnická třída v České republice. Sociálni studia, 2012, roč. 9, č. 3, s. 85-100. ISSN 1214-813X.

NORA, Pierre. Mezi pamětí a historií. Problematika míst. Cahiers du CEFRES, 1998, č. 13, s. 7-31. ISSN 1805-0336.

SAID, Edward W. Invention, Memory, and Place. Critical Inquiry, 2000, roč. 26, č. 2, s. 175-192. ISSN 0093-1896.

SIBLEY, David. Spaces of Exclusion: Home, Locality, Nation. In SIBLEY, David. Geographies of Exclusion. London: Routledge, 1995, s. 90-114. ISBN 0415119243.

SIDIROPULU JANKŮ, Kateřina. Living in the Ostrava Inner City. Socio-Spatial Consequences of Demographic Change in East Central European Cities, the Case of Ostrava, Czech Republic. Ostrava, 2008. Výzkumná zpráva. ConDENSE.

SIDIROPULU JANKŮ, Kateřina. Doma v centru. Obývání vnitřního města Ostravy. „Město a domov "IV. brněnská konference urbánních studií. 7. listopadu. 2013a, Brno: Masarykova univerzita, Fakulta sociálních studií.

SIDIROPULU JANKŮ, Kateřina. Pamět’ romských dělníků - reflexe mocenských vztahů ve výzkumném procesu. Rukopis pro časopis. Biograf, 2013b.

SMOLÍKOVÁ, Marta. Úvodní slovo. Future City Game Ostrava 2015 - město kulturní rozmanitosti. 7. května 2010, Ostrava: Ostrava 2015.

SUTTLES, Gerald D. The Social Construction of Communities. Chicago: The University of Chicago Press, 1972. ISBN 0226781895.

SZALÓ, Csaba. Transnacionální migrace. Proměny identit, hranic a vědění o nich. Brno: Centrum pro studium demokracie a kultury, 2007. ISBN 9788073251369.

TUČKOVÁ, Kateřina. Vyhnání Gerty Schnirch. Brno: Host, 2009. ISBN 9788072943159.

URBAN CENTRUM BRNO. IPRM v problémové obytné zóně [online]. UCB, C2013 [cit. 6. 6. 2013 ]. Dostupné z: http://www.urbancentrum.brno.cz/index.php?nav01=5235\&nav02=5240\&nav03=205 36\&nav04=20824.

WAGNEROVÁ, Alena. Neodsunuté vzpominky. Česká zkušenost pohraničí. Praha: Prostor, 2000. ISBN 8072600451.

WALKER, Ryan C. Searching for Aboriginal/Indigenous Self-Determination: Urban Citizenship in the Winnipeg Low-Cost Housing Sector. Environment and Planning, 2006, roč. 38, č. 12, s. 2345-2363. ISSN 0308-518X.

WINTER, Jay. Foreword. In GLYNN, Irial a J. Olaf KLEIST (eds.). History, Memory and Migration. Perceptions of the Past and the Politics of Incorporation. Macmillan: Palgrave, 2012, s. viii-xi. ISBN 9780230293380.

\section{Autorka}

Kateřina Sidiropulu Janků se jako socioložka zaměřuje na sociální marginalizaci, etnizaci společenských vztahů, migraci, sociologii sousedství a vzpomínání. Pracuje převážně etnografickou metodou, zabývá se také aplikovaným sociálně-vědným výzkumem. Vyučuje kvalitativní sociologické metody a konzultuje veřejnosprávní projekty zaměřené na eliminaci sociální exkluze a odstraňování překážek integrace nejen Romů v české společnosti. Působí na Katedře sociologie FSS MU.

Kontakt: katerinasj@fss.muni.cz 